\title{
STRUCTURAL-COMPOSITIONAL PECULIARITIES OF LITERARY-CRITICAL ARTICLES
}

\section{Anna Savchuk ${ }^{1}$ \\ Marta Fedorchuk ${ }^{2}$}

DOI: https://doi.org/10.30525/978-9934-588-15-0-114

\begin{abstract}
The paper introduces the subject matter of literary-critical discourse as a synthetic notion that combines elements of scholarly, journalistic, aesthetic, argumentative and other discourses forming an independent discursive practice. The purpose of the paper is to outline structural and compositional as well as linguo-rhetorical peculiarities of literary-critical articles. The survey is based on a comparison of data from 13 literary-critical monographs, namely literary-critical articles, written by David Lodge an outstanding British writer, scholar and literary critic. In accordance with the purpose and objectives of the study, a comprehensive analysis was carried out, including the following methods and techniques: general methods such as the method of observation, deduction and induction, analysis and synthesis; linguistic methods: contextual-interpretative method, genre and stylistic analysis with reliance on the methodology of dialogical text interpretation. An attempt at the analysis of the structure and composition of David Lodge's literary-critical works was made. Firstly, we defined the viewpoints on genre as a unit of discourse, paying attention to its properties and peculiarities within the field of literary criticism. Secondly, we analyzed the structural composition of literary-critical articles from 2 angles: static or text building, and dynamic or logical development of thoughts in the text. A short review concludes semantic and rhetorical properties of textual units. Accordingly, two vectors of the compositional-semantic structure of the text were distinguished: compositional proper and logical-compositional. The first was divided into compositional-semantic and formal-compositional. The composition-semantic layout of the text reflects the struc-
\end{abstract}

\footnotetext{
${ }^{1}$ Ph.D. student, Assistant Lecturer at English Philology Department, Ivan Franko National University of Lviv, Ukraine

${ }^{2}$ Scientific Advisor, Candidate of Philological Sciences,

Associate Professor at English Philology Department, Ivan Franko National University of Lviv, Ukraine
} 
tural ways of conveying the components of content through the place of their formulation, the form of expressiveness, and the nature of manifestation of the subject matter. Formal-compositional layout is associated with the development of the beginning, middle and ending of the message. The other side of the compositional and semantic structure of the text is formed by logical and compositional layout, which is related to the reflection of the author's thoughts, namely, it reflects the sequence of arrangement of semantic blocks in the text. In this respect, the structural features of the text are manifested in inductive, deductive or traductive construction. Finally, intertextual markers as form making elements were discussed.

\section{Introduction}

The accomplishments of structural linguistics and text linguistics, neo-rhetoric and functional stylistics, pragmatics and hermeneutics make it possible to return the scientific focus to the line of exploration of literary criticism, which was formed under the influence of philosophy, theory of literature, sociology and aesthetics.

A review of the characteristics and features of literary-critical discourse has been considered in the writings of such researchers as Halperin, 1981; Boriev, 1981; Skurko, 1984; Epstein, 1988; Waltz, 1990; Alekseiev, 2000; Ruzhentseva, 2001; Kozhuna, 2006; Zatselin, 2006; Dmytrovsky, 2006; Krylov, 2007; Hovoruchina 2018 and others.

The relevance of the study is highlighted by the lack of special studies of literary-critical discourse as a special type of discourse from the standpoint of modern linguistics, as well as shortage of analysis based English language material. Existing research in the areas of literary studies (B. Berger, M. Holona, K. Wais, J. Piachel, H. Richter, S.D. Artamonov, V.I. Berozkina, N.Ya. Diakonova, E.P. Zykova, I.V. Tikhomirova, N.A. Khokhlova), literary criticism (A.H. Bocharov, L.A. Shubin, O.M. Tsivkach, V.L. Voronov, S.P. Istratova) and journalism (E. Murbina, E.P. Prokhorov, M.K. Barmankulov) do not reflect, on the one hand, the complexity of the cognitive and communicative-pragmatic essence of literary-critical discourse, and, on the other, the interests of the linguistically oriented typology of texts. At the same time, studies of empirical material at the pragmatic macro-level of literary-critical discourse are important to enhance understanding of empirical constraints, the sequence of speech acts, functional relationships, 
and framework structuring. Finally, the linguo-stylistic parameters of literary-critical articles as a special type of text are not fully defined.

Taking into account the abovementioned points, the purpose and objectives of the study, a holistic approach was applied, using the main contemporary methods and techniques:

- general methods such as the method of observation, deduction and induction, analysis and synthesis, comparison and modeling;

- linguistic methods: contextual-interpretative method the method of component analysis, genre and stylistic analysis with reliance on the methodology of dialogical text interpretation suggested by O. Selivanova [14, p. 336].

Firstly, we define the viewpoints on genre as a unit of discourse, paying attention on its properties and peculiarities within the field of literary criticism. Secondly, we analyze the structural composition of literary-critical articles considering 2 aspects: static or text building, and dynamic or logical development of thoughts in the text. A short review concludes semantic and rhetorical properties of textual units. Finally, intertextual markers as form making elements are discussed.

\section{Genre approach to analysis of literary-critical discourse}

Modern linguistic researches view the genre as a unit of discourse, a kind of global textual strategy that controls the text-forming process genristic strategy. The genristic strategy is used in the process of discursive activity together with the strategies of compositional construction (referential, teleological, elocutive, receptive, metatextual). J.R. Martin has noted that it's important to understand that genres are not just a set of formal structures that flow into meaning. Bhatia, referring to Lotman's concept of "the essence of culture as memory" (Lotman et al. 1975:19) sees genres as combinations of cultural and psychological perspectives that provide a "collective mechanism for storing information (and transmission from generation to generation) (Lotman et al. 1975: 20). The significance of genre categories, therefore, lies in their cognitive and cultural value, and the purpose of genre theory is to outline the implicit knowledge of genre users.

T.V. Yakhontova believes that genres are threefold phenomena that organically combine socio-communicative, socio-cognitive and proper linguistic aspects. The researcher also emphasizes the dualism of genres, 
which are simultaneously processes and products of communication, dynamic and static entities, since each genre is inevitably modified as new text is generated and at the same time serves as an example for constructing other texts - realizations of this genre - through the implementation of this genre [18, p. 85]. A. Devitt describes the genre as "rhetorical, dynamic and flexible" [4].

Because genre has such a significant impact on how people use language, within the chain they enter into "retrospective" and "prospective" relationships with the genres preceding and following in the chain and progressively lead to hybridization and the assimilation of the previous and subsequent genres.

Genre specificity determines the structural features of the text, affects its layout and verbal representation, resulting in a generalized model of the typical text (T.S. Liashenko, A.L. Malinovskaya, N.D. Tamarchenko, S.M. Yavorskaya).

\section{Compositional Structure of Literary-Critical Articles}

In this part, an attempt at the analysis of the structure and composition of David Lodge's literary-critical works was made. A balanced approach has been carried out according to the method of A.E. Babailova [1, p. 53], who first noted that the concept of compositional and semantic structure of the text includes 2 aspects: static or text building, and dynamic or logical development of thoughts in the text. Accordingly, two vectors of the compositional-semantic structure of the text are distinguished: compositional proper and logical-compositional. The first is divided into compositional-semantic and formal-compositional. The composition-semantic layout of the text reflects the structural ways of conveying the components of content through the place of their formulation, the form of expressiveness, and the nature of manifestation of the subject matter. Formal-compositional layout is associated with the development of the beginning, middle and ending of the message.

The other side of the compositional and semantic structure of the text is formed by logical-compositional layout, which is related to the reflection of the author's thoughts, namely, it reflects the sequence of arrangement of semantic blocks in the text. In this respect, the structural features of the text are manifested in inductive, deductive or traductive construction. 
Formal-compositional structure of a literary-critical article is associated with the development of the beginning, middle and ending of the article. It consists of an introductory part, main body and a final part.

Introductory part consists of a heading (with or without a subheading) and a beginning. The heading might be viewed as a representative part of literary-critical articles. It is considered to be a starting point of the presentation of a particular literary-critical topic. Researchers agree on the viewpoint that the main task of a heading is to attract readers' attention and urge him to read the full text.

Research has revealed that headings of literary-critical articles are multifunctional. Along with the nominative function, titles of literary-critical articles perform informative, intriguing, evaluative, advertising and prognostic functions, more often than not comprising a combination of these functions, for example: Analysis and Interpretation of the Realist Text: Ernest Hemingway's 'Cat in the Rain' [12] and Towards a Poetics of Fiction: An Approach Through Language [12] perform informative function; Ambiguously Ever After: Problematic Endings in English Fiction [12], The Novelist Today: Still at the Crossroads? [13], What is Literature? [10], Strictly Confidential [13] perform intriguing function.

Subheadings are not common for literary-critical articles. Only three literary-critical monographs contain subheadings, while others do not. In all cases, the headings perform an informative function:

Title: The Novel Now

Subtitle: Theories and practices [6]

Title: Composition, distribution, arrangement

Title: Virginia Woolf

Subtitle: Chapter Two of A Room of One's Own [8]

Subtitle: Form and Structure in Jane Austen's Novels [6]

Title: A kind of business

Subtitle: The academic critic in America [6]

Having analyzed functional peculiarities of headings and subheadings, we concluded that titles that perform nominative and informative functions are formal, direct, devoid of expressiveness and convey the main idea of the text in a reduced form. These titles are represented by nominative constructions of:

- the names of literary figures, linguists, and philosophers: Ernest Hemingway, Gertrude Stein, Lawrence, Dostoyevsky, Bakhtin; Roman Jack- 
obson, Virginia Woolf, Simone de Beauvoir, Sigmund Freud, Karl Marx and Friedrich Engels, Michel Foucault, Tzvetan Todorov, Jacques Lacan, Jacques Derrida, Bertolt Brecht;

- the names of the authors and their works: Vladimir Nabokov: Pnin; Umberto Eco: The Name of the Rose; J.M. Coetzee: Elizabeth Costello; Henry James: Daisy Miller, Arnold Bennet: 'The Old Wives' Tale'; Oscar Wilde: The Ballad of Reading Gaol;

- nomination of a theoretical problem and/or literary period: Dialogue in the Modern Novel; Mimesis and diegesis in modern fiction; Towards a Poetic of Fiction: An Approach through Language; Modernism, Antimodernism and Postmodernism; Types of Description; Metaphor and Context; The Realistic Tradition.

Formal characteristics of headings expressing nominative-informative function, apart from nominative case, are introduced by possessive case: Jakobson's Theory; Don's Diary, Joyce's Choices, Simon Gray's Diaries, John Boorman's Quest, Alan Bennett's Serial Autobiography. Frequent use of the construction "noun+and+noun" was recorded: Criticism and Realism; Drama and Film; Metaphor and Context; with possible extensions: Milan Kundera, and the idea of the author in modern criticism; Middlemarch and the idea of the classic realist text; Graham Greene and the Anxiety of Influence.

Thus, headings that perform the nominative-informative function are inherent in scholarly and academic conventions. Traditionally, such titles are represented by anthroponyms and terms of literary, linguistic, philosophical, and psychological spheres.

Along with headlines that perform nominative and informative functions, there are also headlines that are intriguing and promotional in nature, which shows features characteristic of journalistic discourse. Such headlines include the means of artistic expression and rhetorical devices that reflect David Lodge's inventiveness and talent as a writer. They allow us to figuratively reimagine the subject of the description, also some headings include an element of famous quotes and proverbs.

Among stylistic devises of the phonological level were found the following: alliteration (Don's Diary, , Fitzgerald's Fear of Flesh, Literary Criticism and Literary Creation, Bye-Bye Bech?, Fact and Fiction in the Novel, Choices and Chance in Literary Composition; Poetry, Prose and Poetic), 
assonance (Anglo-American Attitudes), rhyme (Joyce's Choices, Criticism and Realism).

The use of a rhetorical question in the title primarily serves the purpose of attracting attention and enhancing the perception of information: What is Literature? What is Realism? Bye-Bye Bech? Why Do I Write? How Successful Is Hard Times? What Kind of Fiction Did Nabokov Write? The Novelist Today: Still at the Crossroads? Crearive Writing: Can it/ Should it be Taught?).

Literary-critical headings are characterized by allusiveness. The critic frequently resorts to word play. Although, the comparison of language and play was first made in the works on F. de Saussure and O. Potebnia, the theory of game origin and language functioning belongs to Ludwig Wittgenstein, an Austrian philosopher, logician, linguist. He was a founder of a broad interpretation of the term "language game", according to which any kind of language-related activity is a game and that in most cases, the meaning of a word is its use. Wittgenstein's concept of language game receives a new interpretation introduced by E. Spranger (1922) in the concept of "life forms": Mailer and Female; Suck Cess; Ambiguously Ever After: Problematic Endings in English Fiction; Turning Unhappiness into Money: Fiction and the Mark: Henry Green: The Writer's Writer Writer; Joyce's Choices; Kierkegaard for special purposes, Waiting for the End: Current Novel Criticism, The Uses and Abuses of Omniscience: Method and Meaning in Muriel Spark's The Prime of Miss Jean Brodie, Objections to William Burroughs; Samuel Beckett: Some Ping Understood; Heminway's Clean, Well-lighted, Puzzling Place; Utopia and Criticism: The Radical Longing for Paradise; Through the No Entry Sign: Deconstruction and Architecture; Crosscurrents in Modern Criticism; The Novelist at the crossroads.

The distribution of evaluative functions of headings of literary-critical articles are less numerous: The Best of Young American Novelists, 1996 (The Year of Henry James); Foster's Flawed Masterpiece (Consciousness and the Novel); Waugh's Comic Wasteland (Consciousness and the Novel); D. H. Lawrence: Genius, Heretic, Classic (1985) (Write On); Structural Defects (Write On). Such titles contain evaluative lexis, both positive (the best, genius, masterpiece) and negative (flawed, defects, wasteland), creating a certain focus of perception, positive and approving, or negative and critical attitude to the analyzed work. 
The results of our analysis indicate that the functions of literary-critical titles are primarily distributed as follows: titles are regarded as performing a nominative and informative function, advertising, intriguing and evaluative function. The purpose of the latter is mainly to attract attention. Subheadings are not numerous and serve predominantly an informative function, which is to provide general information about the forthcoming article, or an explanatory function. It should be emphasized that the division of functions is due to the pragmatic attitude of the critic.

The next element of the composition is the beginning. It sets the reader to a certain perception of the subsequent text. It should be mentioned that it directs the reader's attention not to the phenomena or facts, which will be discussed in the main body of the text, but to the prerequisites, circumstances, essential for further reading. The action is intended to compel the reader to read the full text of the article, to contact him/her, to prepare for the perception of critic's opinions and conclusions about a literary work, an approach or/and a writer. Literary-critical beginnings do not have a specific scheme of construction, they can be compressed or expanded, provide different information, and therefore have their own diversities. The results of the analysis give us a reason to take as a basis the classification of A. Malynovska, who distinguished between descriptive, evaluative, and expositive types of beginning.

The expository kind of beginning contains information about the prerequisites for the origin of the work or the creation of the works, the author's reflections on the creative principles and credo of the artist, the influence of a particular approach of literature on the outlook of the writer; author's thoughts on the topic and the basic concept of the work. The expository beginning, according to its main task, is filled with literary terms and names of novelists, fictional characters and quotations. It greatly facilitates the reader's understanding of the subtleties of the art of further information in the text of the article and the author's motives related to the evaluation of the novel.

The biographical beginning contains information about the biographical outline: facts are presented that highlight the main moments of the artist's life and activities: "ANTHONY BUFGESS HARDLY knew his mother, who died in circumstances as poignant and dramatic as any novelist could invent. His father, waiting to be demobbed from the Army in 1919, came 
home to Manchester on leave to find his wife and daughter corpses, victims of Spanish flu, while his infant boy lay burbling in his cot. The father, Burgess suspects, subconsciously resented his son's survival, and sought to snuffle off parental responsibility on to the widow he married a few years later. She was the busy landlady of a pub where he played the bar piano, with two grown-up daughters of her own, and little time or love to spare for her stepson. There was no Oedipal phase in Burgess's childhood, and he grew up to regret the absence of passion and tenderness in his family relationships - the "emotional coldness that was established then and which, apart from other faults, has marred my work." It is, I suppose, true that, for all their energy and gusto, Anthony Burgess's novels are somewhat lacking in emotional warmth, though it is not a judgment I should have presumed to make. That he has made it himself is typical of his unflinchingly candid autobiography" [13, p. 63].

In the above biographical fragment, information about the main moments of the author's life is presented in a descriptive and retrospective manner.

The informative beginning generally presents the main information about a literary phenomenon and is introduced by author's definition: 1) "THE STREAM OF CONSCIOUSNESS" was a phrase coined by William James, psychologist brother of the novelist, Henry, to characterize the continuous flow of thought and sensation in the human mind. Later it was borrowed by literary critics to describe a particular kind of modern fiction which tried to imitate this process, exemplified by, among others, James Joyce, Dorothy Richardson and Virginia Woolf." [9, p. 42] 2) "DEFAMILIARIZATION is the usual English translation of ostranenie (literally, "making strange"), another of those invaluable critical terms coined by the Russian Formalists. In a famous essay first published in 1917, Victor Shklovsky argued that the essential purpose of art is to overcome the deadening effects of habit by representing familiar things in unfamiliar ways" [9, p. 53] 3) "APORIA is a Greek word meaning "difficulty, being at a loss", literally, "a pathless path", a track that gives out. In classical rhetoric it denotes real or pretended doubt about an issue, uncertainty as to how to proceed in a discourse. Hamlet's "To be or not to be" soliloquy is perhaps the best-known example in our literature. In fiction, especially in texts that are framed by a storytelling situation, aporia is a favourite device of narrators to arouse curiosity in their audience, or to emphasize the extraordinary nature of the story they are tell- 
ing. It is often combined with another figure of rhetoric, "aposiopesis", the incomplete sentence or unfinished utterance, usually indicated on the page by a trail of dots" [9, p. 219-220].

The informative beginnings are not aimed at conveying opinions, evaluating or criticizing. The validity and factual information about a literary phenomenon determines absence of the subjectivity and figurative expression. In the informational beginning, the widespread use of neutral vocabulary as well as proper names might be observed, whereas epithets, tropes such as comparisons and metaphors are omitted. The emotional and expressive effect is achieved by expressive syntax: elliptical expressions and imitation of spoken language.

In the descriptive beginning, the description of literary or stylistic elements are provided. The main feature of the descriptive beginning is its laconic layout. This quality is due to the use of elliptical and simple sentences in the form of asynchronous enumeration. The expressiveness of the fragment is also facilitated by the rhetorical question at its beginning and the stylistic order of the words of the second and last sentences. All the above syntactic and lexical means create a stylistic effect of the sardonic attitude of the author to the depicted one, which predetermines a certain evaluation tonality of the text: "WHEN DOES A NOVEL BEGIN? The question is almost as difficult to answer as the question, when does the human embryo become a person? Certainly the creation of a novel rarely begins with the penning or typing of its first words. Most writers do some preliminary work, if it is only in their heads" [9, p. 4].

The evaluative beginning highlights the overall assessment of the represented work, the creativity of the artist, the literary phenomena, and their roles in the development of literature: 1) "Middlemarch has achieved a unique status as both paradigm and paragon in discussion of the novel as a literary form. Indeed it is scarcely an exaggeration to say that, for many critics, Middlemarch is the only truly representative, truly great Victorian novel - all other candidates, including the rest of George Eliot's fiction being either too idiosyncratic or too flawed" [6, p. 45] 2) "Vladimir Nabokov was a literary genius. There is no other word with which to describe a writer who in mid-life became a stylistic virtuoso in a language that was not his mother tongue" [11] 3) "PHILIP ROTH'S OUTPUT of fiction in the seventh decade of his life has been astonishing for both qual- 
ity and quantity. It has been to critics and fellow-novelists a spectacle to marvel at, an awe-inspiring display of energy, like the sustained eruption of a volcano that many observers supposed to be - not extinct, certainly, but perhaps past the peak of its active life" [8] 4) "The achievement of Sigmund Freud (1856-1939) would appear to be so well-known that no significant modern intellectual history could omit his radical approaches to interpreting the dream-state and the prominence he gave to unconscious drives in general" [8] 5) "CHARLES DICKENS IS arguably the greatest of all writers in the English language after Shakespeare, and so has attracted almost as much critical and scholarly attention" [10] 6) "Although literary biography appears to be exceedingly popular with the educated reading public, there is a death of theory behind this form of writing, and a good deal of uncertainty, therefore, about the appropriate criteria to apply to any particular specimen of it, such as Christopher Sykes's Evelyn Waugh" [12, p. 54].

Researchers tend to distinguish within the subject matter of the evaluative beginning two types: one with a neutral style of presentation and one with an emotional character. The above examples $(4,6)$ can be attributed to the first type. The narrative unfolds quietly, thorough explanations of the critic, so the most important role in the construction of the text is played by syntactic structures: complex subordinate sentences. The conciseness of the evaluation in this case is also facilitated by various epithets which form imaginative means, as well as emphasize the individuality of the author's assessment:

For the evaluation of emotional character, the use of imaginative means, syntactic and stylistic devices, evaluative vocabulary, expressive phrases built on vivid metaphors are typical. The following fragments $(1-3,5)$ are examples of concentrated metaphoricity in which individual formations prevail.

All types of beginnings, apart from their specific functions of informing for presenting literary or biographical data, conveying history and development of the literary period or concept, description and evaluation, also have a common function - to prepare the reader for the perception of further information contained in the main body of the text.

Our study shows that most of the beginnings contain valuable information. This gives grounds for claiming that the work moves from the stage preceding the assessment to the stage of direct evaluation: in the beginning, the author makes a general assessment of the work, which allows the reader to predict the content of the subsequent text. This does not in any 
way diminish interest in the article as the reader is constantly finding something new, unexpected for him/her. He/she is interested in the evidence of the given statements, the analysis of the facts presented in the main part of the article.

In the main part, David Lodge develops the main points of information, their content is characterized by thoroughness. Here, the reader is thoroughly acquainted with the creative work of the novelist, the essential moments of his biography; its creative principles, role in the development of a certain direction of literature and the influence of the latter on the creative credo of the artist are analyzed. The content, structure, ideological orientation of a literary piece are considered. The main body can be of descriptive, narrative or/and argumentative in nature and varies from one page to twenty, depending on the subject matter and author's pragmatic aims.

The final part summarizes the process of accumulation, deepening and specification of evaluative information, performing an integrative function. In the end, the assessment goes into the synthesis stage: the evaluative information contained in the main part is repeated, acquiring the final character. The integrating function is also clearly evident in the interaction of the ending/ closing with beginning/ opening: 1) "In twenty-odd lines we have covered enough events to fill an entire novel in the hands of another writer. This kind of writing does indeed depend on the reader's familiarity with a more conventional and realistic fictional discourse to make its effect. Deviations can only be perceived against the norm" [9, p. 188] 2) "Adventures of a Suburban Boy is an effortlessly enjoyable read, containing many droll anecdotes which make one laugh out loud, but it is far deeper than the usual show-biz memoir" $[13$, p. 23] 3) "To sum up: the concept of a period, whether in history at large or in literary history, is not a fact, but an interruption, a human selection and grouping of facts for human purposes, collectively generated and modified by an endless process of redescription... There is no single period style for the modern period, but a variety of styles. But this variety can be reduced to an untellable order if we refer it ti what is constant and finite in literature as a signifying system, mapping the diachronic on the grid of the synchronic" [12, p. 75] 4) "A 'literary' reading of the Orwell and Wilde texts alike is essentially a process of identifying and interrelating recurrent features which are thematically significant, the difference being that whereas these features are foregrounded by Wilde's poetic language, they are much less visible in 
the language of Orwell's text, either because the foreground-background perspective is much shallower or because the thematic motifs are deliberately buried in the foregrounding. In this respect, 'A Hanging' is like much realistic fiction. But what is realism?" [10, p. 28].

A certain sequence of compositional elements, as well as the pragmatic orientation of each of them, which determines the choice and use of linguistic means, provide for the gradual realization of the basic communicative intention - to give a grounded assessment on the basis of a detailed analysis of a work of literature or a literary representative. Evaluation of a represented literary notion goes through three stages of its formation: from the general evaluation through the analytical, based on evidence and arguments, to the final.

\section{Intertextual markers as structural features of literary-critical discourse}

Every scholarly text is based on texts written by precursors in this field $[2$, p. $87 ; 3$, p. 230], and therefore hypertext information is an integral part of literary-critical discourse [16, p. 90], which forms a significant segment in David Lodge's scholarly work and implements the textual category of intertextuality. The concept of marking intertextual relations is a key part of discussions about intertextual relations, which are realized in various kinds of quotations, indirect speech and background references. The notion of marking is primarily related to a conscious, deliberate, expressive, materialized reference in the text, that is, an updated reference to other texts.

The phenomenon of citation is an integral part of the analyzed monographs. Quotation is considered as one of the expressions of the textual category of intertextuality, which is realized by entering into the text fragment of another text or expression [15, p. 656]. It is customary to distinguish between direct citation, or direct quotation, which accurately reproduces another's expression, and indirect quotation, that is, indirect speech.

According to the purposes of introduction in the text, the following types of quotations are distinguished: 1) a quotation-example, needed, first of all, for the visual and material presentation (illustration) of another fragment of the text. The example citation is chosen as the most exponential in formulating of some of the borrowed knowledge. In many cases, it is also accompanied by standardized structures and expressions that emphasize its illus- 
trative nature, for example: that is (i.e.), to give an example, to illustrate: Whichever viewpoint is adopted, moreover, linguistic phenomena always present two complementary facets, each depending on the other. For example: "The ear perceives articulated syllables as auditory impressions. But the sounds in question would not exist without the vocal organs" [11, p. 44]; 2) a quotation-argument that is primarily used in the evidence function to give credence and reliability to the views and conclusions presented. This type of quotation is often one of the considerations in the general system of evidence and is represented by phrases like, because, it follows that, that is why, which are integrated into the holistic system of evidence produced by the author: "the Movement was very great because «for the first time a challenge is thrown down, not by individuals... but a more or less coherent group, to the monopoly of British culture sustained for generations by the London haute-bourgeoisie" [13, p. 40]; 3) a quote-substitution is used to express the view of the author of the text with the words of someone else. In this case, its replacement function comes to the forefront. The replacement quote reflects the overlapping views of two (or more) authors. This quote preserves another participant's language style, expressiveness, and terminology. Such quotations are often accompanied by explanations such as: this means, in other words, otherwise (specifically, more accurately) formulated, as.... has written/pointed out; to be more precise. In addition, such quotes may contain phrases and sentences that are subject to an old-type knowledge nomination: "Rene Wellek had this to say: "The nature of this issue is conveniently illustrated by a comment of Bateson's: "The boss's armchair is no doubt: ... a functional consequence of the plot and characterization; it is the addition of greenness to the chair, a non-functional detail, that is the mark of the realistic convention" [7, p. 44].

Since citation can be included in the fabric of the text in the form of a heterogeneous mass of quotations, they can be roughly divided into two large groups: non-artistic quotations (excerpts from works of scientists, public figures, philosophers) and artistic quotations (excerpts from works of art). The first group can be presented only in the form of monological statements, while the second - In monological and dialogical manner.

Given their structure, David Lodge's monographs are most characteristic of the following structural types of citations: 1) inclusions in the form of individual words and phrases: «Handsome» (rather than conven- 
tionally pretty or beautiful - a hint of masculine will-to-power, perhaps, in that androgynous epithet), «clever» (an ambiguous term for intelligence, sometimes applied derogatively...), and «rich», with all its biblical and proverbial associations of the moral dangers of wealth $[9$, p. 5]; 2) individual sentences or complex of several sentences: "In these phrases we seem to hear Emma's own, rather self-satisfied description of her relationship with her governess, one which allowed her to do «just what she liked" [9, p. 6]; 3) a paragraph or several paragraphs: «The metalanguage within such a text refuses to acknowledge its own status of writing. The text outside the area of inverted commas claims to be the product of no articulation, it claims to be unwritten...» $[6$, p. 50]; 4) one-to-several page citations: in the article "Analysis and Interpretation of the Realist Text: Ernest Hemingway's 'Cat in the Rain'» 4 pages include the full story [12, p. 33-36]; in the article "Oedipus: or, The Practice and Theory of Narrative» the short story «Guess What Happened?» is presented in 2 pages [12, p. 46-47]. The last type of quotation is introduced mainly for illustrative purposes.

In principle, an indirect speech introduces an analytical model of language transference of someone else's speech. Analysis is a necessary feature of indirect speech, which is inseparable from transference of someone else's speech. Formal transformation involves the need for compression, changes in the deictic perspective, and a variety of repetitions. The most typical types of indirect speech were identified as: implicit indirect speech, converted to substative/noun (the idea/suggestion of): Such forms enable us to verify Ransom's wise suggestion that 'the meter-and-meaning process is the organic act of poetry, and involves all its important characters [8, 288], or verbal-prepositional combinations (suggested that...): "He [Jacques Raverat] suggested that writing, as an artistic medium, was limited by being superimposed frames" [10, p. 225];

Transferred indirect speech with the disappearance of the original subject-predicative structure and mandatory indication of the source (according to, in accordance with): "According to Jakobson, Mayakovsky was interested in resurrection" [8, p. 213]; "According to Bateson and Shakevitch, the functional or linguistically significant elements in a work of realistic prose fiction - those which determine our understanding" [2, p. 46]. At the same time, we have also found deviant forms of transfer of someone else's speech, namely, phrases involving the object and the subject of cognition, 
for example: "One might almost say that in Daisy Miller James anticipated Ernest Hemingway's theory of the short story" [11, p. 53] or "Valéry's theories are usefully discussed by Laurence Lerner in his book The Truest Poetry" [2, p. 11], which in a brief form actualize the intertextual relations of one concept with another, in relation to the subject of knowledge and at the same time its result. In general, indirect speech constructs create less intertextual tension in terms of dialogism and contrast of interacting layers.

David Lodge's scholarly literary-critical writings also contain a considerable number of references and background references, i.e. references only to the title of the source, author, year of publication, and, as a rule, their number does not exceed the number of indirect speech and citations. The reference acts as a reproduction of someone else's speech in the text of the fabric of the new research and exists as an indicator of the significance of the research [5, p. 152]. In general, all the above-mentioned means of intertextual interactions are a form of realization of relations to the knowledge obtained from precursors, introduction of methodological characteristics in a particular cognitive and epistemic situation in science. They reflect the scholarly objectivity and accuracy of researchers, that is, they characterize the personality of the scholar in the moral aspect [17, p. 36].

Along with the manifestation of the systematic use of foreign texts, one should speak of an individual style of citation, in accordance with an individual style of thinking, a sense of proportionality, inner harmony and balanced assessment. The predominance of intertextual signals in the language of literary-critical articles confirms the processes of information consolidation and coagulation, constantly occurring in scholarly knowledge.

\section{Conclusion}

Nowadays, linguistic studies are multidisciplinary by nature; therefore, different discursive practices form the scope of researchers' investigation. Having scrutinized the peculiarities of synthetic literary-critical discourse, we moved forward to a genre approach towards its structure and composition, taking literary-critical articles as empirical material.

We concluded that:

1. Genre specificity determines the structural features of the text, affects its layout and verbal representation, resulting in a generalized model of the typical text. 
2. The analysis has shown that the structure of literary-critical articles is fairly homogeneous. Formal-compositional structure of a literary-critical article is associated with the development of the beginning, middle and ending of the article. It consists of an introductory part, main body and a final part. This indicates both the dominant nature of structure for this genre and the fact that peripheral deviations are also possible.

3 . The functions of literary-critical titles are primarily distributed as follows: titles are regarded as performing a nominative and informative function, advertising, intriguing and evaluative function, usually performing multiple functions. The purpose of the latter is mainly to attract attention.

4. Subheadings are not numerous and serve predominantly an informative function, which is to provide general information about the forthcoming article, or an explanatory function. It should be emphasized that the division of functions is due to the pragmatic attitude of the critic.

5. The beginning sets the reader to a certain perception of the subsequent text and directs the reader's attention not to the phenomena or facts, which will be discussed in the main body of the text, but to the prerequisites, circumstances, essential for further reading. The action is intended to compel the reader to read the full text of the article, to contact him/her, to prepare for the perception of critic's opinions and conclusions about a literary work, an approach or/and a writer.

6. Literary-critical beginnings do not have a specific scheme of construction, they can be compressed or expanded, provide different information, and therefore have their own diversities. The results of the analysis give us a reason to distinguish between descriptive, evaluative, and expositive types of beginning.

7. In the main part David Lodge develops the main points of information, their content is characterized by thoroughness. Here, the reader is thoroughly acquainted with the creative work of the novelist, the essential moments of his biography; its creative principles, role in the development of a certain direction of literature and the influence of the latter on the creative credo of the artist are analyzed. The content, structure, ideological orientation of a literary piece are considered. The main body can be of descriptive, narrative or/and argumentative in nature and varies from one page to twenty, depending on the subject matter and author's pragmatic aims. 
8. The final part summarizes the process of accumulation, deepening and specification of evaluative information, performing an integrative function. In the end, the assessment goes into the synthesis stage: the evaluative information contained in the main part is repeated, acquiring the final character. The integrating function is also clearly evident in the interaction of the ending/closing with beginning/ opening.

9. A certain sequence of compositional elements, as well as the pragmatic orientation of each of them, which determines the choice and use of linguistic means, provide for the gradual realization of the basic communicative intention - to give a grounded assessment on the basis of a detailed analysis of a work of literature or a literary representative. Evaluation of a represented literary notion goes through three stages of its formation: from the general evaluation through the analytical, based on evidence and arguments, to the final.

10. Hypertext information is an integral part of literary-critical discourse, which forms a significant segment in David Lodge's scholarly work and implements the textual category of intertextuality. The concept of marking intertextual relations is a key part of discussions about intertextual relations, which are realized in various kinds of quotations, indirect speech and background references. The notion of marking is primarily related to a conscious, deliberate, expressive, materialized reference in the text, that is, an updated reference to other texts.

\section{References:}

1. Babaylova A.E. (1987). Tekst kak produkt, sredstvo i obekt kommunikatsii pri obuchenii nerodnomu yazyku. Sotsiopsikholingvisticheskie aspekty. Saratov

2. Bakhtin M.M. (1981). The Dialogic Imagination: four essays, trans. by Emerson, C. \& Holquist, M. Austin, TX. University of Texas Press.

3. Broich U., Pfister M. (1985). Intertextualität: Formen, Funktionen, anglistische Fallstudien, Tübingen.

4. Devitt A.J. (1997). Writing Genres. Genre, Frames and Writing in Research Settings. Brian Paltridge, John Benjamins Publishing.

5. Kotyurova M.P., Bazhenova E.A. (2008). Kul'tura nauchnoy rechi: tekst $i$ ego redaktirovanie: uchebnoe posobie. M.: Flinta. Nauka.

6. Lodge D. (1990). After Bakhtin. Essays on Fiction and Criticism. London $\&$ New York: Routledge.

7. Lodge D. (1966). Language of Fiction. Essays in Criticism and Verbal Analysis of the English Novel. London: Routledge@Paul.

8. Lodge D. (1988). Modern Criticism and Theory. London. 
9. Lodge D. (1992). The Art of Fiction. Penguin Books.

10. Lodge D. (2015). The Modes of Modern Writing: Metaphor, Metonymy, and the Typology of Modern Literature. Bloomsbury Revelations.

11. Lodge D. (2006). The Year of Henry James, The story of a Novel. London: Penguin.

12. Lodge D. (1981). Working with Structuralism. Boston, London \& Henley: Routledge \& Kegan Paul.

13. Lodge D. (1986). Write On. Penguin Books.

14. Selivanova E.A. (2002). Osnovy lingvisticheskoy teorii teksta $i$ kommunikatsii.

15. Selivanova O.O. (2006). Suchasna linhvistyka: terminolohichna entsyklopediya. Poltava: Dovkillya.

16. Fateeva N.A. (2000). Intertekst $v$ mire tekstov. Kontrapunkt intertekstual'nosti.

17. Chernyavskaya V.E. (2014). Kommunikatsiya $v$ nauke: normativnoe $i$ deviantnoe. Lingvisticheskiy $i$ sotsiokul'turnyy analiz rechevogo vozdeystviya. Moskva: Direkt-Media.

18. Yakhontova T.V. (2009). Lingvistichna genologiya naukovoi komunikatsii. 